\title{
Nowoczesna terapia ostrych zespołów wieńcowych oparta na prasugrelu - dostępna dla polskiego pacjenta
}

\author{
Modern therapy of acute coronary syndromes based on prasugrel \\ - available to Polish patients
}

\author{
Beata Wożakowska-Kapłon (i) \\ I Klinika Kardiologii i Elektroterapii Świętokrzyskiego Centrum Kardiologii w Kielcach \\ Wydział Lekarski i Nauk o Zdrowiu Uniwersytetu Jana Kochanowskiego w Kielcach
}

\section{Streszczenie}

Chorzy z ostrymi zespołami wieńcowymi poddawani pierwotnej angioplastyce powinni otrzymywać podwójną terapię przeciwpłytkową kwasem acetylosalicylowym w skojarzeniu z inhibitorem P2Y $\mathrm{Y}_{12}$. Preferowanymi inhibitorami P2Y $\mathrm{Y}_{12}$ są prasugrel i tikagrelor. Leki te umożliwiają osiągnięcie szybszego, większego i bardziej stałego stopnia zahamowania receptorów płytkowych $\mathrm{P}_{2} \mathrm{Y}_{12}$ i prowadzą do lepszych wyników klinicznych niż zastosowanie klopidogrelu. Prasugrel jest przeciwwskazany u pacjentów z wywiadem przebytego udaru/przemijającego ataku niedokrwiennego i ogólnie nierekomendowany u chorych powyżej 75. roku życia oraz u chorych z małą masa ciała (< $60 \mathrm{~kg})$, jako że w tych grupach chorych nie wykazano przewagi prasugrelu nad klopidogrelem. Jeśli jednak po przeprowadzonej analizie korzyści i ryzyka zapadnie decyzja o zastosowanie prasugrelu u chorych starszych niż 75 lat bądź lżejszych niż $60 \mathrm{~kg}$, to dawka podtrzymująca powinna być zmniejszona do $5 \mathrm{mg} /$ dobę.

Tikagrelor może wywoływać przejściowe napady duszności, co niekiedy stanowi przyczynę odstawienia leku. Ani prasugrelu, ani tikagreloru nie powinno się stosować u chorych po krwawieniu do ośrodkowego układu nerwowego stosujących dousutną antykoagulację oraz u chorych z umiarkowaną bądź ciężką dysfunkcją wątroby. Jeśli żaden z tych leków nie jest dostępny dla pacjenta bądź są przeciwwskazane, to klopidogrel powinien być zastosowany w ich miejsce. Ze względu na ograniczenia ekonomiczne w wielu przypadkach polscy pacjenci byli dotąd pozbawieni możliwości nowoczesnej strategii leczenia silnymi inhibitorami $\mathrm{P}_{2} \mathrm{Y}_{12}$, ale pojawił się na rynku preparat generyczny prasugrelu.

Słowa kluczowe: ostre zespoły wieńcowe, leki przeciwpłytkowe, prasugrel

Folia Cardiologica 2020; 15, 1: 49-55

\section{Wstęp}

Corocznie około 160 tys. osób w Polsce zapada na ostre zespoły wieńcowe (ACS, acute coronary syndrome), spośród których u około $41 \%$ rozpoznaje się niestabilną chorobę wieńcową (UA, unstable angina), u około $28 \%$ zawał serca bez uniesienia odcinka ST (NSTEMI, non-ST-elevated myocardial infarction), a u $31 \%$ zawał serca z uniesieniem odcinka ST (STEMI, ST-elevated myocardial infarction) [1]. Przezskórną interwencję wieńcową ( $\mathrm{PCl}$, percutaneous coronary angioplasty) przeprowadza się u 59\% chorych z rozpoznaniem zawału serca (MI, myocardial infarction) i chociaż dzięki wdrożeniu nowoczesnych metod leczenia udało się zmniejszyć śmiertelność szpitalną do mniej niż $10 \%$, to wysoka pozostaje śmiertelność w okresie 1 roku po wypisaniu ze szpitala u pacjentów hospitalizowanych

Adres do korespondencji: prof. dr hab. n. med. Beata Wożakowska-Kapłon, I Klinika Kardiologii i Elektroterapii, Świętokrzyskie Centrum Kardiologii, ul. Grunwaldzka 45, 25-736 Kielce, e-mail: bw.kaplon@poczta.onet.pl 
z powodu MI. W zależności od sposobu terapii i miejsca hospitalizacji, a także wieku pacjentów zawiera się ona w granicach 6,5-24\% [2]. Podstawową metodą farmakoterapii ACS jest podwójna terapia przeciwpłytkowa (DAPT, dual-antiplatelet therapy), tj. skojarzenie kwasu acetylosalicylowego (ASA, acetylsalicylid acid) z inhibitorem receptora płytkowego P2Y $\mathrm{Y}_{12}$. Dowody naukowe przemawiają za tym, że DAPT obniża ryzyko wystąpienia zakrzepicy w stencie w zakresie szerokiego spektrum - od zdarzeń ostrych do bardzo późnych - oraz zmniejsza częstość występowania spontanicznego MI [3]. Ryzyko krwawienia u pacjentów stosujących DAPT wykazuje proporcjonalny związek z czasem jej trwania zarówno w ciągu 1 roku, jak i w przypadku terapii trwającej dłużej niż 1 rok, dlatego zasadne jest zindywidualizowane podejście oparte na ocenie ryzyka niedokrwienia w porównaniu z ryzykiem krwawienia [4].

\section{Rodzaje inhibitorów receptorów płytkowych $\mathrm{P}_{2} \mathrm{Y}_{12}$}

Obecnie w doustnej terapii skojarzonej z ASA stosuje się trzy leki z grupy inhibitorów receptorów płytkowych

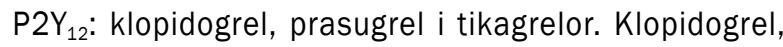
choć jest najczęściej stosowanym inhibitorem receptorów płytkowych $\mathrm{P}_{2} \mathrm{Y}_{12}$ w leczeniu ACS w Polsce, to według obowiązujących wytycznych u chorych z ACS leczonych PCl bądź u chorych ze STEMI stanowi alternatywę dla prasugrelu bądź tikagreloru jedynie wtedy, gdy te ostatnie są niedostępne bądź pozostają przeciwwskazane. Klopidogrel cechuje znaczna zmienność odpowiedzi farmakodynamicznej zależna od kilku czynników, również od polimorfizmów genetycznych. Klopidogrel w randomizowanych badaniach klinicznych u chorych z ACS poddawanych $\mathrm{PCl}$ okazał się mniej skuteczny zarówno od prasugrelu (badanie TRITON-TIMI 38 [TRial to Assess Improvement in Therapeutic Outcomes by Optimizing Platelet InhibitioN with Prasugrel-Thrombolysis In Myocardial Infarction]), jak i od tikagreloru (badanie PLATO [Platelet Inhibition and Patient Outcomes]) $[5,6]$.

Rodzaj terapii i czas stosowania DAPT u chorych z zespołami wieńcowymi zależy od sytuacji klinicznej (ostry bądź przewlekły zespół wieńcowy), strategii leczenia (zabiegowa bądź zachowawcza) oraz ryzyka krwawienia (wysokie bądź niskie ryzyko krwawienia). Te elementy determinują wybór leku przeciwpłytkowego i okres podawania DAPT. Jeśli zachodzi konieczność zastosowania terapii przeciwkrzepliwej, to dodatkowo modyfikuje ona sposób leczenia przeciwpłytkowego.

W porównaniu z klopidogrelem prasugrel umożliwia osiągnięcie szybszego, większego i bardziej stałego stopnia zahamowania receptorów płytkowych P2Y $_{12}$. W badaniu TRITON-TIMI 38 u pacjentów ze STEMI bądź z ACS w przypadku których uznano, że anatomia tętnic wieńcowych jest odpowiednia do wykonania PCl, złożony punkt końcowy (zgon z przyczyn sercowo-naczyniowych, MI niezakończony zgonem lub udar mózgu) wystąpił rzadziej o 18\% ( $p=0,002)$ u osób leczonych prasugrelem niż u chorych stosujących klopidogrel. Tych wyraźnych korzyści klinicznych nie stwierdzono jednak u osób w wieku 75 lat i starszych ani u chorych z małą masą ciała (< 60 kg). Jednocześnie zaobserwowano znamiennie większą liczbę krwawień u chorych w grupie leczonej prasugrelem w porównaniu z grupą leczoną klopidogrelem. Prasugrelu, w ramach badania TRITON-TIMI 38, nie przebadano u pacjentów z ACS leczonych zachowawczo. Wyniki badania TRITON-TIMI 38 upoważniają do stosowania prasugrelu u chorych po koronarografii, jeśli występują u nich wskazania do wykonania PCI. Leczenie wstępne jest dopuszczalne jedynie u pacjentów ze STEMI poddawanych interwencji pierwotnej.

Tikagrelor jest bezpośrednim, doustnym, odwracalnym inhibitorem receptorów płytkowych $P 2 Y_{12}$, a jego okres półtrwania w osoczu wynosi około $12 \mathrm{~h}$, co implikuje jedno podanie 2 razy/dobę. W badaniu PLATO wykazano, że tikagrelor był skuteczniejszy niż klopidogrel u pacjentów z ACS, którzy niezależnie od ostatecznej strategii rewaskularyzacji (tj. planowe lub nieplanowe postępowanie inwazyjnie), byli wstępnie leczeni klopidogrelem przy przyjęciu do szpitala.

\section{Terapia inhibitorem receptorów płytkowych P2Y ${ }_{12}$ u chorych z ACS}

\section{Chorzy ze STEMI}

Dane na temat tego, kiedy należy rozpoczynać podawanie inhibitora receptorów płytkowych $\mathrm{P}_{2} \mathrm{Y}_{12}$ u pacjentów ze STEMI, są ograniczone, jednak uznaje się, że jak najwcześniejsze podanie leku może być zasadne w celu uzyskania wczesnej skuteczności leczenia, natomiast w przypadkach, w których rozpoznanie STEMI nie jest pewne, należy rozważyć opóźnienie podania inhibitora receptorów płytkowych $\mathrm{P} \mathrm{Y}_{12}$ do momentu poznania anatomii zmian w tętnicach wieńcowych [7]. W okresie okołozabiegowym (przed lub najpóźniej w momencie $\mathrm{PCl}$ ) i pozabiegowym u pacjentów poddawanych pierwotnej PCI preferowanymi inhibitorami receptorów płytkowych $\mathrm{P}_{2} \mathrm{Y}_{12}$ są prasugrel (dawka nasycająca $60 \mathrm{mg}$, dawka podtrzymująca $10 \mathrm{mg} 1 \times$ /d. doustnie [p.o., per os].) oraz tikagrelor (dawka nasycająca $180 \mathrm{mg}$, dawka podtrzymująca $90 \mathrm{mg} 2 \times /$ d. p.o.). Leki te charakteryzują się szybszym początkiem działania, większą siłą działania oraz lepszymi klinicznymi wynikami leczenia niż klopidogrel [7]. Podanie silnego inhibitora receptorów płytkowych P2Y 12 (prasugrelu lub tikagreloru), a klopidogrelu jedynie wtedy, gdy prasugrel lub tikagrelor są niedostępne lub pozostają przeciwwskazane, ma I klasę zaleceń z najwyższym (A) poziomem wiarygodności danych. Leczenie prasugrelem bądź tikagrelorem w skojarzeniu z ASA powinno być prowadzone przez 12 miesięcy, chyba że występują przeciwwskazania, 
takie jak nadmierne ryzyko krwawienia. Dawki inhibitorów receptorów płytkowych $\mathrm{P}_{2} \mathrm{Y}_{12}$ u pacjentów poddawanych pierwotnej PCl lub niepoddanych leczeniu reperfuzyjnemu to w przypadku prasugrelu dawka nasycająca $60 \mathrm{mg}$ p.o., a następnie dawka podtrzymująca $10 \mathrm{mg} /$ dobę. U pacjentów z masą ciała nieprzekraczającą $60 \mathrm{~kg}$ zaleca się dawkę podtrzymującą $5 \mathrm{mg} /$ dobę. Prasugrel jest przeciwwskazany u pacjentów po wcześniejszym udarze mózgu. U pacjentów w wieku co najmniej 75 lat prasugrelu zasadniczo się nie zaleca, ale jeżeli takie leczenie zostanie uznane za niezbędne, to należy stosować dawkę podtrzymującą $5 \mathrm{mg} /$ dobę. Dawka nasycająca w przypadku tikagreloru to $180 \mathrm{mg}$ p.o., a następnie dawka podtrzymująca $90 \mathrm{mg} 2 \mathrm{razy} /$ dobę. Klopidogrel podaje się w dawce nasycającej 600 mg p.o., a następnie w dawce podtrzymującej $75 \mathrm{mg} /$ dobę.

\section{Chorzy z NSTEMI}

U pacjentów z NSTEMI zaleca się DAPT obejmujące ASA oraz silny inhibitor receptorów płytkowych $\mathrm{P}_{2 \mathrm{Y}_{12}}$ (prasugrel lub tikagrelor). Klopidogrel powinno się stosować tylko wtedy, gdy prasugrel lub tikagrelor są niedostępne lub pozostają przeciwwskazane bądź u pacjentów wymagających doustnego leczenia przeciwkrzepliwego (klasa zaleceń I, poziom wiarygodności danych B). Rozpoczęcie leczenia inhibitorem receptorów płytkowych $\mathrm{P}_{2} \mathrm{Y}_{12}$ ustaIono w wytycznych na podstawie przedziałów czasowych, w których dany lek oceniano w badanich rejestracyjnych, tj. rozpoczęcie terapii tak szybko, jak to możliwe i bezpieczne w przypadku tikagreloru i klopidogrelu lub po ustaleniu wskazań do wykonania $\mathrm{PCl}$ na podstawie anatomii tętnic wieńcowych w przypadku prasugrelu. Prasugrel podaje się w dawce nasycającej $60 \mathrm{mg}$, następnie $10 \mathrm{mg} /$ dobę w połączeniu z ASA. U pacjentów z masą ciała mniejszą niż 60 kg zaleca się dawkę podtrzymującą 5 mg. U pacjentów w wieku ponad 75 lat zasadniczo nie zaleca się prasugrelu, ale jeżeli uzna się to za konieczne, to powinno się stosować dawkę $5 \mathrm{mg}$. Inhibitor receptorów płytkowych P2Y 12 zaleca się w połączeniu z ASA przez 12 miesięcy, chyba że występują przeciwwskazania, takie jak nadmierne ryzyko krwawienia [4, 7-9].

\section{Przezskórna interwencja wieńcowa w przewlekłych zespołach wieńcowych}

U pacjentów poddawanych planowej PCl wskazane są ASA i klopidogrel, natomiast stosowanie prasugrelu lub tikagreloru można rozważać tylko u wybranych pacjentów w określonych sytuacjach związanych z wysokim ryzykiem planowego stentowania (np. złożone zabiegi PCl, takie jak stentowanie pnia lewej tętnicy wieńcowej oraz zabiegi w leczeniu przewlekłego zamknięcia tętnicy wieńcowej) lub u pacjentów z wywiadami zakrzepicy w stencie podczas leczenia klopidogrelem (klasa zaleceń Ilb, poziom wiarygodności danych C) [9].

\section{Porównanie prasugrelu z tikagrelorem}

Nie ma zbyt wielu danych z randomizowanych badań klinicznych odnoszących się do porównania tikagreloru z prasugrelem u pacjentów z ACS, ale w opublikowanym randomizowanym badaniu PRAGUE-18 (Comparison of Prasugrel and Ticagrelor in the Treatment of Acute Myocardial Infarction) stwierdzono podobny profil bezpieczeństwa i skuteczności tikagreloru i prasugrelu w warunkach pierwotnej PCI [10].

Badaniem, ogłoszonym w 2019 roku, które odbiło się szerokim echem w świecie kardiologicznym, jest ISAR-REACT 5 (The Intracoronary Stenting and Antithrombotic Regimen: Rapid Early Action for Coronary Treatment) badanie IV fazy, dobrze zaprojektowane, randomizowane, wieloośrodkowe międzynarodowe badanie kliniczne, które nie było sponsorowane przez firmy farmaceutyczne [11]. Wykazano w nim wyższość prasugrelu nad tikagrelorem w zakresie ograniczenia występowania złożonego punktu końcowego składającego się ze zgonu, zawału serca lub udaru mózgu w ciągu roku od randomizacji u pacjentów z ACS, a efekty te nie wiązały się ze wzrostem ryzyka wystąpienia krwawienia w grupie leczonej prasugrelem [11]. Wyniki badania wywołały żywą dyskusję i sprowokowały, jak się wydaje niesłuszne i bezzasadne, zarzuty dotyczące protokołu badania i jego realizacji $[12,13]$.

Założeniem badania ISAR-REACT 5 była weryfikacja hipotetycznej wyższości tikagreloru nad prasugrelem u pacjentów z ACS. Społeczność kardiologiczna powszechnie spodziewała się wyników zgodnych z założeniami. Przeciwne do oczekiwanych wyniki potwierdzające wyższość prasugrelu można traktować jako tym bardziej wiarygodne.

Autorzy polemiki dotyczącej badania ISAR-REACT 5 krytykują jego otwarty charakter, niedoszacowanie zjawiska niestosowania zaleconej terapii czy przeprowadzanie kontrolnych wizyty w formie rozmów telefonicznych. W rzeczywistości jednak cechy te stanowią siłę badania i świadczą o warunkach bliższych codziennej praktyce klinicznej, a nie jedynie cechujących skrupulatnie wyselekcjonowaną do badania klinicznego grupę pacjentów.

Zarzuty dotyczące metody analizy typu ITT (intention-to-treat - populacja zgodna z zaplanowanym leczeniem) i włączenia do niej pacjentów, którzy nie byli leczeni przypisanym lekiem, są zaskakujące zarówno dlatego, że metoda ta jest powszechnie akceptowana i stosowana w badaniach klinicznych, jak i dlatego, że odsetek pacjentów włączonych dzięki tej metodzie do analizy był porównywalny w grupach leczonych prasugrelem i tikagrelorem. Trudno zatem przyjąć, że różnica pod względem wystąpienia głównego punktu końcowego (zgon, zawał serca lub udar mózgu) w ciągu roku po randomizacji między grupą leczoną tikagrelorem (9,8\%) i grupą leczoną prasugrelem $(6,8 \%)$ nie jest istotna [12, 13].

Trudno również zgodzić się z zarzutami wobec badania ISAR-REACT 5 wynikającymi z porównania jego wyników z wynikami badania TRITON-TIMI 38 [5, 11]. Zaskakujące 
jest stanowisko, że różnice między częstością występowania pierwszorzędowego punktu końcowego wynoszącą 6,9\% w badaniu ISAR-REACT 5 i 9,9\% w badaniu TRITON-TIMI 38 uznano za nieoczekiwane i trudne do wyjaśnienia. Za komentarz do tego stwierdzenia niech posłużą słowa Orvilla Wrighta: „Gdybyśmy wszyscy pracowali z założeniem, że to, co jest pierwotnie uznawane za prawdziwe, jest prawdą, nie byłoby nadziei na postęp".

W badaniu ISAR-REACT 5 analizie dotyczącej pierwszorzędowego punktu końcowego poddano populację pacjentów ITT uwzględniającą wszystkich chorych według losowego przydziału do grup bez względu na faktycznie zastosowane leczenie. Pacjentów oceniano od czasu randomizacji (punkt zerowy) do zgonu, wycofania zgody lub do dnia ostatniego kontaktu z chorym. W grupie leczonej tikagrelorem ocenie poddano 2012 chorych, zaś w grupie leczonej prasugrelem - 2006 chorych.

W ocenie bezpieczeństwa leczenia przeanalizowano populację pacjentów mITT (modified intention to treat). Modyfikacja polegała na tym, że do analizy bezpieczeństwa włączono wszystkich pacjentów, którzy otrzymali co najmniej jedną dawkę losowo przydzielonego leku i byli obserwowani do 7 dni po odstawieniu badanego leku. W przypadku tikagreloru analizie poddano 1989 pacjentów, a w przypadku prasugrelu była to grupa 1773 pacjentów. Oznacza to, że w przypadku tikagreloru różnica między ocenianymi grupami wynosiła 23 pacjentów, natomiast w grupie leczonej prasugrelem - 233 pacjentów. Tak duża liczba chorych wyłączonych z analizy w grupie leczonej prasugrelem i duża różnica w porównaniu z grupą leczoną tikagrelorem wynikały głównie z planu badania, w którym zakładano obowiązkowe zastosowanie rutynowego leczenia tikagrelorem przed zabiegiem u wszystkich chorych w grupie przyjmującej tikagrelor oraz brak takiego postępowania w grupie otrzymującej prasugrel wśród pacjentów z ACS bez uniesienia odcinka ST. W konsekwencji dawkę nasycająca leku podano mniejszej liczbie pacjentów w grupie leczonej prasugrelem niż w grupie leczonej tikagrelorem. W praktyce oznaczało to, że analizie bezpieczeństwa nie poddano tych pacjentów, którym nie podano ani jednej dawki leku. Byli to pacjenci, których po koronarografii nie zakwalifikowano do leczenia prasugrelem. U 184 spośród tych 233 pacjentów nie potwierdzono rozpoznania ACS. Trudno się zgodzić z zarzutami, jakoby nie wskazano przyczyn wyłączenia pacjentów z analizy. Przyczyny te podano w zestawieniu zawartym w publikacji badania ISAR-REACT $[5,11]$.

Bardzo dobre wyniki leczenia prasugrelem u pacjentów poddawanych pierwotnej PCI w przebiegu STEMI stwierdzono w badaniu rejestrowym wśród 89 tys. angielskich pacjentów leczonych w latach 2007-2014 prasugrelem, klopidogrelem bądź tikagrelorem. W analizie śmiertelności 30-dniowej i 1-rocznej po zastosowaniu metody propensity score matching i metody wieloczynnikowej regresji logistycznej wykazano istotnie statystycznie najniższą śmiertelność 30-dniową i 1-roczną w populacji pacjentów leczonych prasugrelem w porównaniu z grupami leczonymi tikagrelorem i klopidogrele. Śmiertelność chorych otrzymujących tikagrelor i klopidogrel była na podobnym poziomie.

\section{Zmiana leczenia między doustnymi inhibitorami receptorów płytkowych $\mathrm{P}_{2} \mathrm{Y}_{12}$}

W dokumencie „Uaktualnione stanowisko ESC dotyczące stosowania podwójnej terapii przeciwpłytkowej w chorobie wieńcowej w 2017 roku, przygotowane we współpracy z EACTS" [4] po raz pierwszy jednoznacznie określono możliwość i sposób zamiany leczenia między doustnymi inhibitorami receptorów płytkowych $\mathrm{P}_{2} \mathrm{Y}_{12}$. U pacjentów z ACS, którzy przyjmowali wcześniej klopidogrel, zaleca się we wczesnym okresie po przyjęciu do szpitala zamiane klopidogrelu na tikagrelor podany w dawce nasycającej $180 \mathrm{mg}$, bez względu na czas przyjęcia i dawkę nasycającącą klopidogrelu, chyba że występuja przeciwwskazania do zastosowania tikagreloru (klasa zaleceń I, poziom wiarygodności danych B). W przypadku wystąpienia działań niepożądanych/nietolerancji leczenia można rozważyć dodatkową zamianę w obrębie doustnych inhibitorów receptorów płytkowych $\mathrm{P}_{2} \mathrm{Y}_{12}$ zgodnie z zaproponowanym poniżej algorytmem (klasa zaleceń II, poziom wiarygodności danych C) (ryc. 1) [4].

Należy zauważyć, że zamiana dokonywana w warunkach ostrych zawsze powinna przebiegać z podaniem dawki nasycającej. W sytuacji kiedy następuje zamiana klopidogrelu na prasugrel bądź tikagrelor, podanie dawki nasycającej odbywa się bez względu na wcześniejszy czas podania i dawkę klopidogrelu. W warunkach przewlekłych zamiana również jest możliwa, ale wówczas dawka nasycająca obowiązuje jedynie przy zamianie tikagreloru na prasugrel bądź na klopidogrel, zawsze jednak w warunkach przewlekłych obowiązuje zachowanie 24-godzinnego odstępu od podania ostatniej dawki wcześniej stosowanego inhibitora receptorów płytkowych P2Y $_{12}$.

\section{U jakich pacjentów należy rozważyć podanie prasugrelu?}

Prasugrel jest inhibitorem receptorów płytkowych $\mathrm{P}_{2} \mathrm{Y}_{12}$ z wyboru u pacjentów ACS i należy go stosować u odpowiednio dobranych chorych z tym rozpoznaniem. Są to ci chorzy, u których w wywiadzie nie występuje udar mózgu ani przemijający atak niedokrwienny (TIA, transient ischaemic attack) czy czynne patologiczne krwawienie. Należy również pamiętać o konieczności modyfikacji dawki u pacjentów w wieku 75 lat i starszych i/lub z masą ciała mniejszą niż $60 \mathrm{~kg}$. Prasugrel powinien być stosowany u pacjentów z ACS poddawanych pierwotnej lub odroczonej 


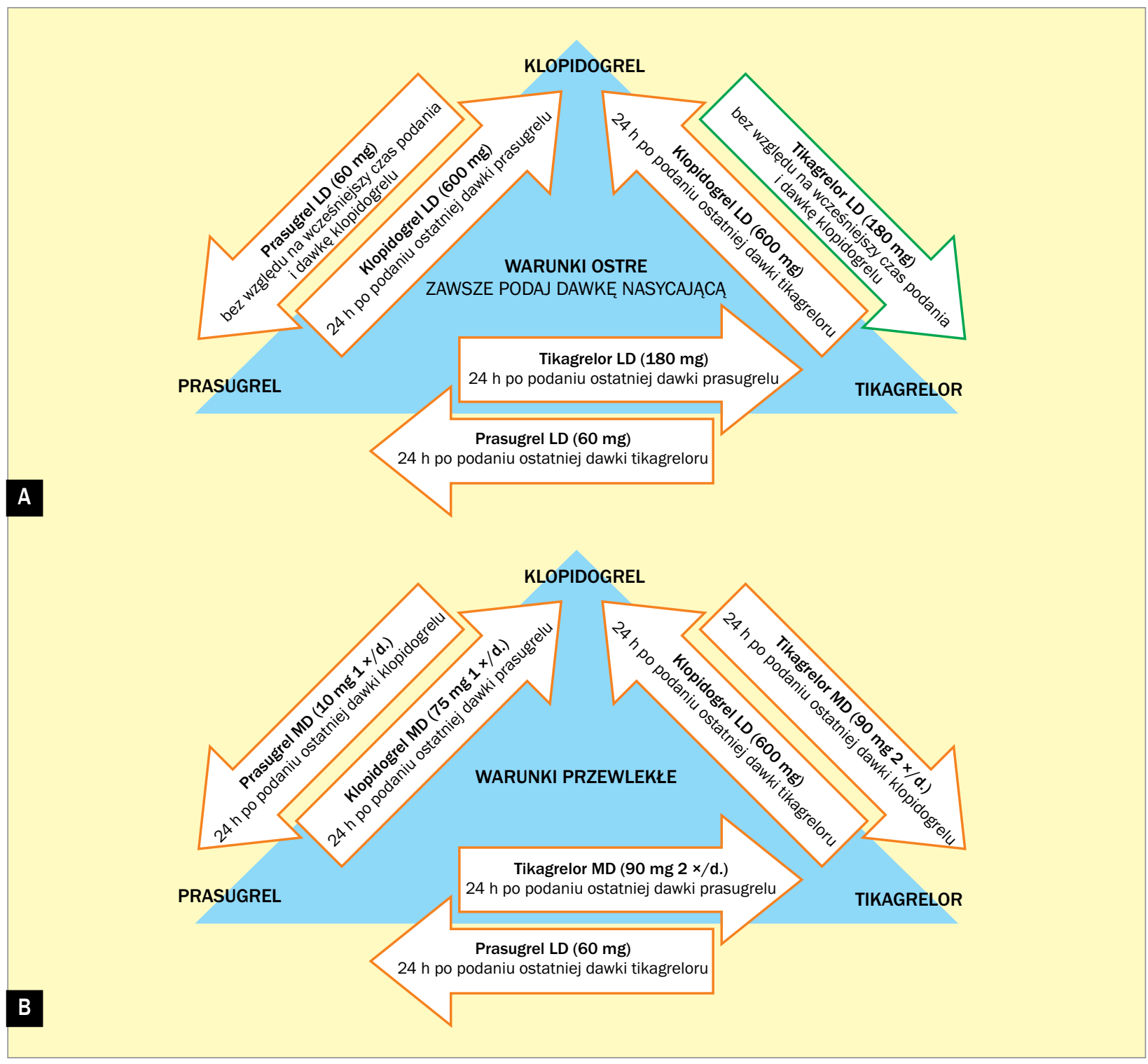

Rycina 1A, B. Algorytm zmiany leczenia w obrębie grupy inhibitorów receptora P2Y ${ }_{12}$ w warunkach ostrych oraz przewlekłych. Poszczególne kolory odnoszą się do klasy zaleceń Europejskiego Towarzystwa Kardiologicznego (ESC, European Society of Cardiology) (zielony - klasa I, pomarańczowy - klasa Ilb). Zielona strzałka skierowana od klopidogrelu do tikagreloru określa jedyny algorytm zamiany leczenia, w odniesieniu do którego są dostępne dane z badań nad pacjentami z ostrymi zespołami wieńcowymi. Nie ma danych dotyczących wyników leczenia (strzałki pomarańczowe) w odniesieniu do innych algorytmów zamiany terapii. Za ostre warunki uznano zamianę leczenia w ramach hospitalizacji; LD - (Ioading dose) dawka nasycająca; MD (maintenance dose) - dawka podtrzymująca (źródło [4])

PCl. Zasadne jest preferowanie tego leku u pacjentów ze STEMI. W przypadku pacjentów z NSTEMI o wyborze in-

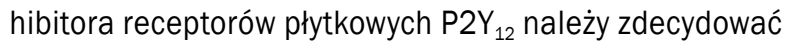
po wykonaniu koronarografii. Codzienna praktyka leczenia ACS w Polsce wskazuje, że obowiązujące od kilku lat wytyczne, w których wyraźnie zaleca się wybór prasugrelu bądź tikagreloru przed klopidogrelem, nie są powszechnie stosowane. Polska jest krajem „klopidogrelowym”, co wynika przede wszystkim z małej dostępności ze względów ekonomicznych dla polskiego pacjenta, preferowanych przez autorów wytycznych, silnych inhibitorów receptorów płytkowych P2Y ${ }_{12}$. Często, niestety, zdarza się sytuacja zaniechania w kolejnych tygodniach czy miesiącach od ACS leczenia nowoczesnym inhibitorem receptorów płytkowych P2 $\mathrm{Y}_{12}$ włączonym w trakcie hospitalizacji właśnie ze względu na ograniczenia finansowe polskich pacjentów bądź też stosowania jednej dawki/dobę zamiast dwóch w przypadku tikagreloru, z tych samych powodów. Dlatego 
pojawienie się na rynku dostępnego cenowo nowoczesnego inhibitora receptorów płytkowych $\mathrm{P}_{2} \mathrm{Y}_{12}$ w postaci leku generycznego - prasugrelu i możliwość zastosowania u chorych leczenia zgodnego z obowiązującymi wytycznymi powinno wpłynąć na zmianę dotychczasowej strategii leczenia ACS u polskich pacjentów. Budzi również nadzieję na zmniejszenie wciąż zbyt dużej śmiertelności w okresie
1 roku po wypisaniu ze szpitala u pacjentów hospitalizowanych z powodu MI.

\section{Konflikt interesów}

Honoraria wykładowe od firm: Adamed, AstraZeneca, Bayer, Gedeon Richter, Sanofi.

\section{Abstract}

Patients with acute coronary syndromes undergoing primary percutaneous coronary intervention should receive dual-antiplatelet therapy, a combination of acetylsalicylic acid and a P2 $Y_{12}$ inhibitor. The preferred P2 $Y_{12}$ inhibitors are prasugrel or ticagrelor. These drugs have a more rapid onset of action, greater potency, and are superior to clopidogrel in clinical outcomes. Prasugrel is contraindicated in patients with previous stroke/transient ischaemic attack, and its use is generally not recommended in patients aged $>75$ years or in patients with lower body weight $(<60 \mathrm{~kg})$ as it has not been associated with net clinical benefit in these subsets. If prasugrel is used in these patients after benefits and risks have been weighted, a reduced maintenance dose $(5 \mathrm{mg})$ is recommended.

Ticagrelor may cause transient dyspnoea at the onset of therapy, which rarely leads to permanent discontinuation. Neither prasugrel nor ticagrelor should be used in patients with a previous haemorrhagic stroke, in patients on oral anticoagulants, or in patients with moderate-to-severe liver disease. When neither of these agents is available (or if they are contraindicated), clopidogrel should be given instead. In most cases, Polish patients have been deprived of modern treatment strategies using potent $\mathrm{P} 2 \mathrm{Y}_{12}$ inhibitors for economic reasons, but generic prasugrel is currently available.

Key words: acute coronary syndrome, antiplatelet agents, prasugrel

Folia Cardiologica 2020; 15, 1: 49-55

\section{Piśmiennictwo}

1. Poloński L, Gierlotka M, Zdrojewski T. Narodowa baza danych zawałów serca AMI-PL i Ogólnopolski rejestr ostrych zespołów wieńcowych PL-ACS. Medycyna Praktyczna, Kraków 2015.

2. Gierlotka M, Zdrojewski T, Wojtyniak B, et al. Incidence, treatment, in-hospital mortality and one-year outcomes of acute myocardial infarction in Poland in 2009-2012 - nationwide AMI-PL database. Kardiol Pol. 2015; 73(3): 142-158, doi: 10.5603/KP.a2014.0213, indexed in Pubmed: 25371307.

3. Mozaffarian D, Benjamin EJ, Go AS, et al. Writing Group Members, American Heart Association Statistics Committee, Stroke Statistics Subcommittee. Heart disease and stroke statistics-2016 update: a report from the American Heart Association. Circulation. 2016; 133(4): e38-e360, doi: 10.1161/CIR.0000000000000350, indexed in Pubmed: 26673558.

4. Uaktualnione stanowisko ESC dotyczące stosowania podwójnej terapii przeciwpłytkowej w chorobie wieńcowej w 2017 roku, przygotowane we współpracy z EACTS. Grupa Robocza Europejskiego Towarzystwa Kardiologicznego (ESC) i Europejskiego Stowarzyszenia Chirurgii Serca i Klatki Piersiowej (EACTS) do spraw stosowania podwójnej terapii przeciwpłytkowej w chorobie wieńcowej. Kardiol Pol. 2017; 75: 1217-1299, doi: 10.5603/KP.2017.0224.

5. Wiviott SD, Braunwald E, McCabe $\mathrm{CH}$, et al. Prasugrel versus clopidogrel in patients with acute coronary syndromes. N Engl J Med. 2007; 357(20): 2001-2015, doi: 10.1056/nejmoa0706482.
6. Wallentin L, Becker R, Budaj A, et al. Ticagrelor versus clopidogrel in patients with acute coronary syndromes. NEngl J Med. 2009; 361(11): 1045-1057, doi: 10.1056/nejmoa0904327, indexed in Pubmed: 19717846.

7. Ibanez B, James S, Agewall S, et al. Wytyczne ESC dotyczące postępowania w ostrym zawale serca z uniesieniem odcinka ST w 2017 roku. Grupa Robocza Europejskiego Towarzystwa Kardiologicznego (ESC) do spraw postępowania w ostrym zawale serca z uniesieniem odcinka ST. Kardiol Pol. 2018; 76: 229-313, doi: 10.5603/KP.2018.0041.

8. Roffi M, Patrono C, Collet JP, et al. Wytyczne ESC dotyczące postępowania w ostrych zespołach wieńcowych bez przetrwałego uniesienia odcinka ST w 2015 roku. Grupa Robocza Europejskiego Towarzystwa Kardiologicznego (ESC) do spraw postępowania w ostrych zespołach wieńcowych bez przetrwałego uniesienia odcinka ST. Kardiol Pol. 2015; 73: 1207-1294, doi: 10.5603/KP.2015.0243.

9. Neumann FJ, Sousa-Uva M, Ahlsson A, et al. Wytyczne ESC/EACTS dotyczące rewaskularyzacji mięśnia sercowego. Grupa Robocza ds. rewaskularyzacji mięśnia sercowego Europejskiego Towarzystwa Kardiologicznego (ESC) i Europejskiego Stowarzyszenia Chirurgii Serca i Klatki Piersiowej (EACTS). Kardiol Pol. 2018; 76: 1585-1664, doi: 10.5603/KP.2018.0228.

10. Motovska Z, Hlinomaz 0, Kala P, et al. PRAGUE-18 Investigators, PRAGUE-18 Study Group. Prasugrel versus ticagrelor in patients with acute myocardial infarction treated with primary percutaneous coronary intervention: multicenter randomized PRAGUE-18 study. 
Circulation. 2016; 134(21): 1603-1612, doi: 10.1161/CIRCULATIONAHA.116.024823, indexed in Pubmed: 27576777.

11. Schüpke S, Neumann FJ, Menichelli M, et al. ISAR-REACT 5 Trial Investigators. Ticagrelor or prasugrel in patients with acute coronary syndromes. N Engl J Med. 2019; 381(16): 1524-1534, doi: 10.1056/ /NEJMoa1908973, indexed in Pubmed: 31475799.

12. Adamski P, Kubica J. ISAR-REACT 5 - czy to badanie powinno zmienić praktykę kliniczną? Folia Cardiol. 2019; 14(5): 483-487, doi: 10.5603/FC.a2019.0099.
13. Kubica J, Jaguszewski M. ISAR-REACT 5 - what have we learned? Cardiol J. 2019; 26(5): 427-428, doi: 10.5603/CJ.a2019.0090, indexed in Pubmed: 31536136.

14. Olier I, Sirker A, Hildick-Smith DJR, et al. British Cardiovascular Intervention Society and the National Institute for Cardiovascular Outcomes Research. Association of different antiplatelet therapies with mortality after primary percutaneous coronary intervention. Heart. 2018; 104(20): 1683-1690, doi: 10.1136/heartjnl-2017-312366, indexed in Pubmed: 29437885. 